\title{
Unplanned Settlements in Saudi Arabia. The Case of Al-Sabeel District, Jeddah
}

\author{
Abdel-Moniem EL-SHORBAGY* ${ }^{*}$ \\ * Corresponding author \\ ${ }^{1}$ Effat University, College of Architecture and Design, Jeddah, SAUDI ARABIA \\ E-mail: aelshorbagy@effatuniversity.edu.sa \\ DOI: 10.24193/JSSP.2020.2.03
}

https://doi.org/10.24193/JSSP.2020.2.03

K e y w o r d s: Al-Sabeel district, Jeddah, unplanned settlements, infrastructure, community participation

\begin{abstract}
A B S T R A C T
Unplanned settlements represent a twentieth-century phenomenon that has been steadily growing on the periphery of almost all cities in the world. These areas are usually overpopulated and characterized by inadequate housing, unpleasant living conditions. Jeddah, a second major city in Saudi Arabia, consists of many unplanned settlements and slums, which affect the future development of its urban and social fabric. This paper intends to explore some essential issues relating to the issues of unplanned settlements in Jeddah through the study, analysis, and assessment of the built environment of Al-Sabeel district, one of the oldest districts in Jeddah. The main objective of this research is to investigate the major physical problems of the deteriorated areas of the district. Thus, the primary purpose is to define a set of recommendations for the upgrading of future unplanned settlements, which will help these informal areas to improve and gradually integrate into the existing urban fabric of the city. Regarding methodology, a qualitative research approach was adopted, which included a literature review, a face-to-face interviews, and field visits to document the physical condition of the built environment of the district. The outcome of the study represents a set of recommendations that indicate the importance of community participation approach as a means of improving the physical condition of the urban environment of Al-Sabeel district.
\end{abstract}

\section{INTRODUCTION}

Unplanned settlements, slums, and informal settlements have varying interpretations and meanings based on the socioeconomic, political, and mainly historical circumstances. The United Nations has defined slums as overcrowded residential areas, characterized by dilapidated housing and lack of essential services such as drinking water and sanitation (UNESCAP, 2015).

From a broader perspective, unplanned settlements are built areas not authorized by the government and illegally settled, while slums denote substandard dwellings in terms of services and infrastructure, building materials, and method of construction (UN-Habitat, 2015). They have also been categorized as "the most deprived form" of settlements, which may not necessarily be illegal (Drakakis-Smith, 1981). Thus, an unplanned settlement specific definition depends on its scale and existing urban context and it is not necessarily to be categorized as a slum, while its residents might not be poor (Minnery et al., 2013). However, it was estimated that approximately one billion persons are living in slums worldwide, and this number is expected to double by 2030 (UN-Habitat, 2016). Out of one billion persons, about 881 million are living in slums in developing countries. The highest number is recorded in Asia followed by Africa and Latin America and the Caribbean. In 2015, it was estimated that approximately $25 \%$ of the world's urban population continued to make their home in an urban slum (UNHabitat, 2015). 
Urbanization represents one of the most critical transformative drivers of the $21^{\text {st }}$ century. Around $54 \%$ of the world's population is living in urban cities and it was estimated that, by 2050, approximately $70 \%$ of the world's population would be living in urban areas (World Cities Report, 2016). Urbanized cities are characterized by unprecedented population growth accompanied by economic change, social and cultural activities, and appropriate livability. However, the nature of urbanization creates several planning challenges, including the provision of sufficient housing and services, health, education, and infrastructure. Thus, the adoption of a New Urban Agenda to achieve world sustainable urbanization for the next twenty years was the primary outcome of the United Nations Conference on Housing and Sustainable Urban Development (Habitat III) in Quito, Ecuador in 2016. This agenda represents a shared vision for a better and more sustainable future, and if well managed, urbanization could be a common and useful tool for sustainable development for both developing and developed countries. In this context, sustainable urbanization and cities are seemingly weaved together to achieve socioeconomic, cultural, and environmental goals (UN-Habitat 3, 2015).

Joan Clos, Under-Secretary-General of the United Nations, believes that if urbanization is not structured, it will adversely affect the future of cities in the developing countries. He argues that this form of urbanization could be the driver behind the formation of slums and unplanned settlements, which represent the most affordable housing solutions to one-third of the global urban population today. Clos also discusses that this type of unplanned urbanization would obstruct cities from implementing their agenda in economic development and social prosperity (UN-Habitat, 2012). Thus, the growing phenomena of setting up informal settlements could be perceived as the logical consequences of urbanization, which allows their residents for housing, services, and infrastructure (Minnery et al., 2013). However, many international policy approaches addressed the problem of these unplanned settlements by suggesting the strategy of demolition and replacement. The demolition approach is perhaps not the appropriate solution because it creates more problems than it solves. For example, it would disturb the life of inhabitants, who represent an essential factor of the urban economy and contribute to the economic growth of their cities (UN-Habitat, 2003). Another essential strategy is the slum upgrading approach that has been adopted by many countries worldwide as a critical component of their urban planning programs. They invest in upgrading both the buildings' physical condition and infrastructure systems such as electricity, water, sanitation, and sewage. Also, the upgrading approach concurrently develops the road network and solves the problems of block accessibility. One of the significant 82 examples of slum upgrading is Zwelisha, a newly upgraded settlement north of Durban, South Africa. The outcome of the upgrade process in Zwelisha was successful due to the imperative role of the community, who participated in achieving a remarkable improvement to tenure security and wellbeing (Patel, 2013). Another pioneering upgrading program was carried out by Surabaya city in Indonesia. In 1969, the city initiated the Kampung Improvement Program (KIP), which became a model for slum upgrading nationally and internationally. The main goal of the KIP was to put the residents of the Kampung slum at the heart of the upgrading development, provide them with the necessary services and infrastructure, and offering livelihood opportunities. This program became one of the significant examples of successful slum upgrading in the world (Das A., King, R., 2019).

The upgrading approach has also been adopted by some Arab countries such as Egypt, Tunisia, and Morocco. In 2008, Egypt issued the Unified Building Law, which deals with issues far wider than urban structures and their locations. It aims not only to reorganize the approach to strategic urban planning but also to create future visions for Egyptian cities. The Unified Building Law emphasizes that informal areas will not be demolished; they will be considered as part of the urban fabric of the city, and they will be provided with statutory benefits of facilities and investments to cope with the planned and serviced areas of the city. Representative examples that employed the strategy of upgrading approach also include Manshiet Nasser and Ezbet el Haggana, the largest long-standing informal areas in Cairo (UN-HABITAT, 2011). Over the last few decades, Saudi Arabia has faced many challenges because of the enormous population growth of unplanned settlements, particularly in major cities such as Jeddah and Riyadh. Saudi Arabia is one of the largest countries in the Arab world, which encompasses an area of approximately $2,149,690 \mathrm{~km}^{2}$ and a population of approximately $34,490,879$ inhabitants (total number of population of Saudi is of 20,768,627). However, the density is of approximately 15.5 persons/sq $\mathrm{km}$. Jeddah is a large city with an area of approximately $5460 \mathrm{~km}^{2}$. It is the second-most populous city in the kingdom, with a population estimated around 4,076,000 as of 2017, which is almost $12 \%$ of the total population of Saudi Arabia (World Population Review, n.d.).

Jeddah is the home to the largest port on the Red Sea, which represents the main gateway to the two holy cities of Makkah and Madinah. The analysis of the city of Jeddah has shown significant problems of the urban structure, including the isolation of the historic area from the rest of the city, moving the center of urban structure to the north of the city, the excessive imbalance between urban growth and sprawl, and, most importantly, the spatial segregation of the unplanned settlements, which in some cases turned into urban slums (Karimia, 2012). Although Jeddah is currently 
enjoying unprecedented growth and is undergoing massive urban development, it faces substantial urban challenges. The significant expansion of the uncontrolled and unplanned settlements in the last century has created complicated problems that affected the urban fabric and infrastructure of the city (UNICEF, 2012). According to the report released by the Municipality of Jeddah in 2008, the city comprises more than 54 unplanned settlements, which occupy around $16 \%$ of its area (Fig. 1) (Al-Malki, Mashael, 2008). It also houses more than one million people living in unplanned settlements, which represents about one-quarter of the city's population. The central four large informal districts in Jeddah are Bani Malik, AlRuwais, Al-Boghdadiyah, and Al-Sabeel (Fig. 2). The majority of these neighborhoods are characterized by the lack of healthy living conditions, proper infrastructure, including water, sewage, electricity, safe roads, and open spaces.

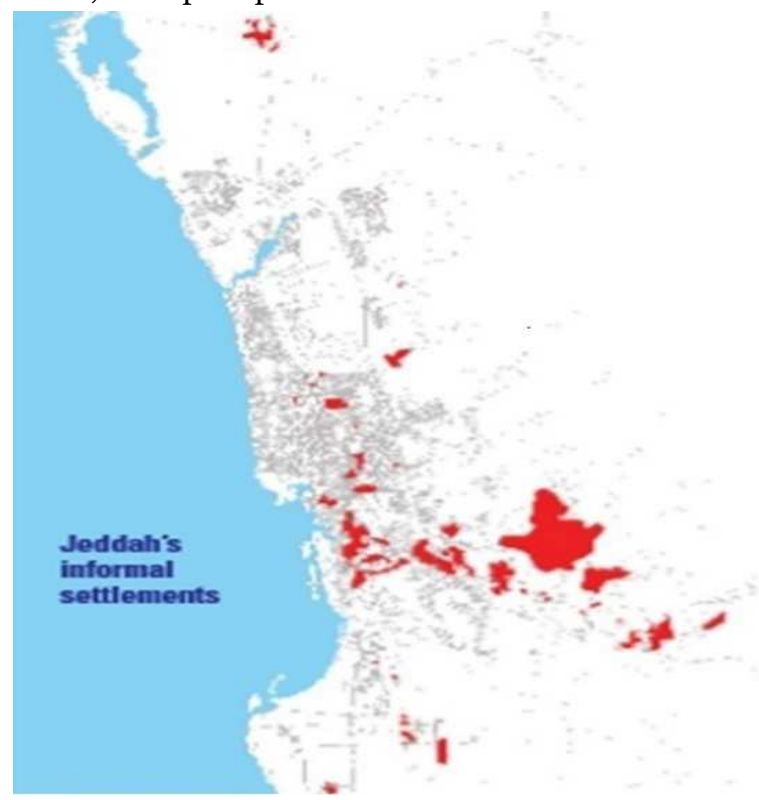

Fig. 1. Informal Settlement in Jeddah (source: UNICEF, 2012).

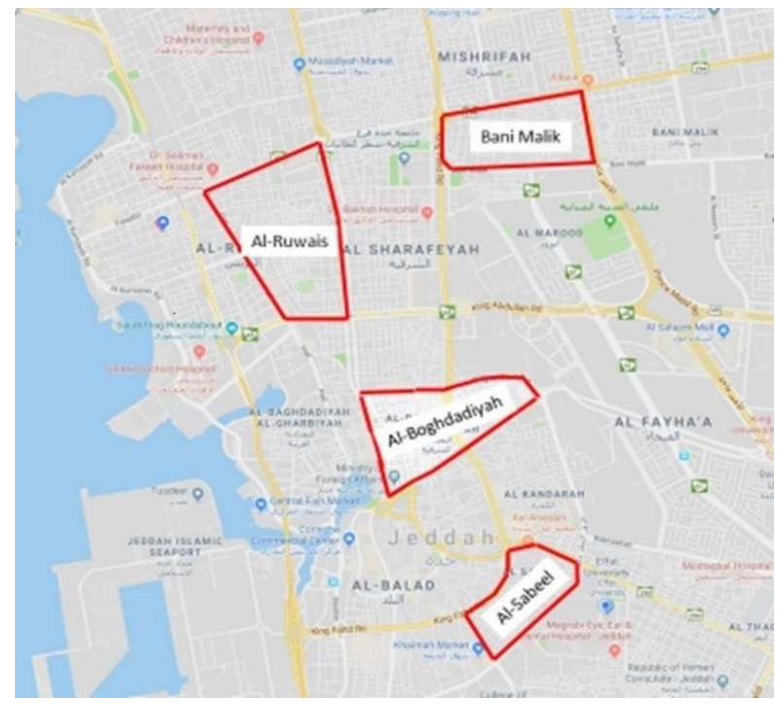

Fig. 2. Main unplanned settlements, Jeddah.
The literature review has also shown that Jeddah's authority has brought the issue of these unplanned settlements to the national scale and suggested comprehensive planning programs. For example, in 2006, a royal decree was issued to approve the establishment of Jeddah Development and Urban Regeneration Company (JDURC), which is a stateowned company, represented by the municipality of Jeddah. The company has a fully independent financial responsibility to prepare and implement urban regeneration programs and projects in Jeddah. In 2008, JDURC initiated the development of Al-Ruwais unplanned settlement, which lies in the center of Jeddah (Fig. 2) and represents the first urban regeneration experience in Jeddah. The primary aim of the project was to improve living condition and provide a new world vision of urban development. However, the project program followed the evacuation-demolition approach to allow for a new cultural landmark for both Jeddah and the country (Fig. 3). Unfortunately, the project did not meet any success, and the residents refused to leave their houses hoping for an improvement and upgrading plan instead of the evacuation option (JDURC, n.d.).

In 2007, Jeddah municipality announced the launch of the re-planning and upgrading program for many of the informal and unplanned settlements in the city, including Al-Sabeel district. As part of the development program, the project aimed to facilitate the transportation system of Al-Sabeel by expanding its main streets. The project included the demolition of 165 buildings in order to increase land availability for the expansion of six streets in the district. Accordingly, the government handed over the appropriate compensation to the owners of the removed buildings, and the demolition process was supervised by relevant government authorities, including the civil defense, telecommunications company, electricity, water and sanitation, traffic, and the police (Ghamdi, 2007). Unfortunately, the municipality pended the project because of a conflict with the contractor and the residents. The majority of the demolished houses have turned into places for criminal activities, and storages for contraband and intoxicants, which consequently pose a threat to the youth of the area. Also, illegal laborers occupied these abandoned houses and increased the population of the area. In a broader sense, we can attribute this problem to the absence of a definite system of commissioning projects and implementing them in a way that ensures the security and safety of citizens (Al-Faraj, 2014).

Within the perspective of these developments, it seems that none of them involved the concept of upgrading and community participation. Instead, the city approached the issue of these settlements from the viewpoint of evacuation and demolition to allow for setting up entirely new modern mega projects. However, Al-Sabeel district is a particular research 
topic because of its unique location in Jeddah city center. It represents a reliable tool for gaining a more in-depth insight into the complex urban phenomenon of unplanned settlements in Jeddah. Al-Sabeel district also allows for the opportunity to explore their changing physical characteristics and their consequences on the urban structure of the city. Although Al-Sabeel faces many different interrelated problems including, socioeconomic, environmental, poverty, poor planning, safety and violence, health, and wellbeing, this research will focus on the physical condition of the district's built environment. The main objective of this research is to identify the essential issues related to the issue of unplanned settlements in Jeddah through the study, analysis, and assessment of the built environment of AlSabeel, namely building conditions, streets network, and infrastructure problems. The primary purpose of this study is to define a set of recommendations for upgrading the physical condition of Al-Sabeel district and future unplanned settlements in Saudi Arabia.

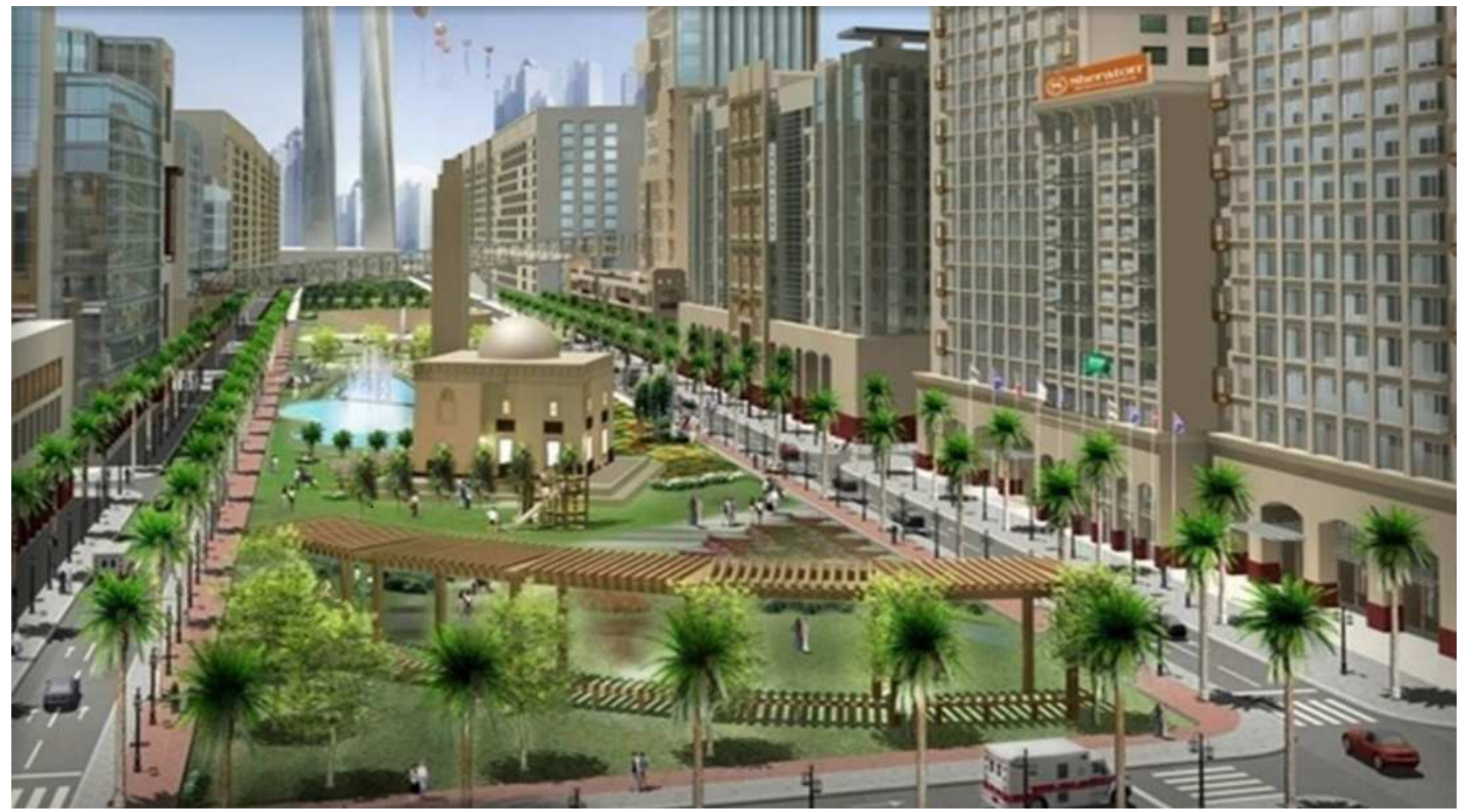

Fig. 3. New proposal for Al-Ruwais unplanned settlement (the evacuation-demolition approach) (source: JDURC, n.d.).

\section{METHODOLOGY OF THE STUDY}

This research represents a preliminary study aiming to identify the physical condition of the built environment in Al-Sabeel district. The study adopted a qualitative research methodology based on an in-depth understanding of the physical built environment of the district provided by the rich experience of residents and their own social situations. Also, the qualitative research relies heavily on purposive sampling strategy, which refers to the deliberate selection of specific settings from which researchers can learn extensively about the issues under examination (Carpenter, C. M., Suto, M., 2008). This methodology can provide essential information about the physical condition of the existing buildings in Al-Sabeel District. The research methodology consisted in three phases; an extensive literature review, a face-to-face interview with the residents of the area, and field visits to document and analyze the physical condition of the existing buildings in a specific study-zone.

a). The study began with collecting the appropriate literature review data and the available information that relates to the research topic and sheds light on the general context of slum problems and upgrading programs.

b). The study also consisted in carrying out some 32 face-to-face interviews with the district's residents to identify the challenges they face. The interviewees responded to a pre-prepared questionnaire survey that was structured on four main aspects, namely general information, building physical condition, infrastructure problems, and mobility and accessibility difficulties (Appendix A). The main intention of the questionnaire was to explore the residents' daily problems, as well as their personal opinions about the physical environment of their district. The research employed the survey interviews as the method of data collection. Data was further analyzed and interpreted to draw recommendations and conclusions. Although the number of interviewees was relatively small, it managed to reflect the actual context and image of the area and enriched us with a realistic response to the residents' living conditions.

c). The last phase included the selection of a small sample study-zone, which was systematically and thoroughly investigated (Fig. 4). The field study was conducted on foot by the author and took place from 22 
December 2019 to 7 January 2020. The primary purpose of the field study was to develop an actual image of the present situation in the area and collect as much data as possible. The study-zone included 40 houses (Fig. 5), for which the author mapped their physical condition, recorded their heights and materials. Notes were also taken about the infrastructure condition, such as water, sewage, electricity, and the road network (Appendix B).

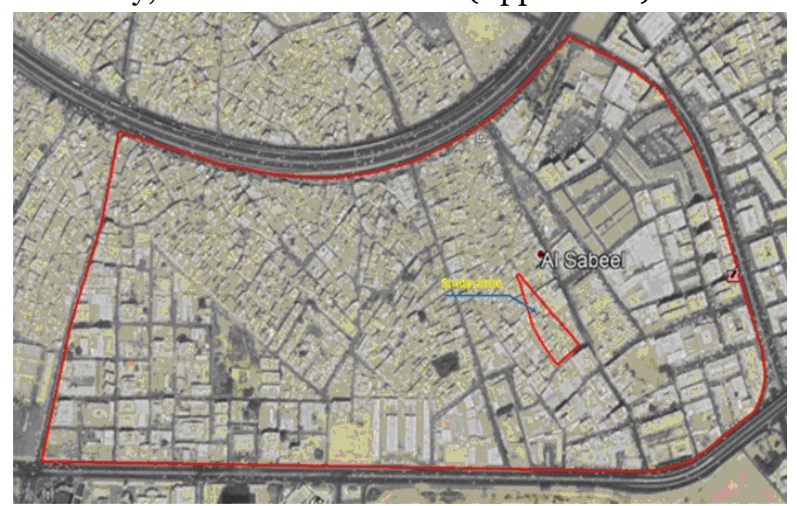

Fig. 4. Al-Sabeel district and the study area (source: Google maps).

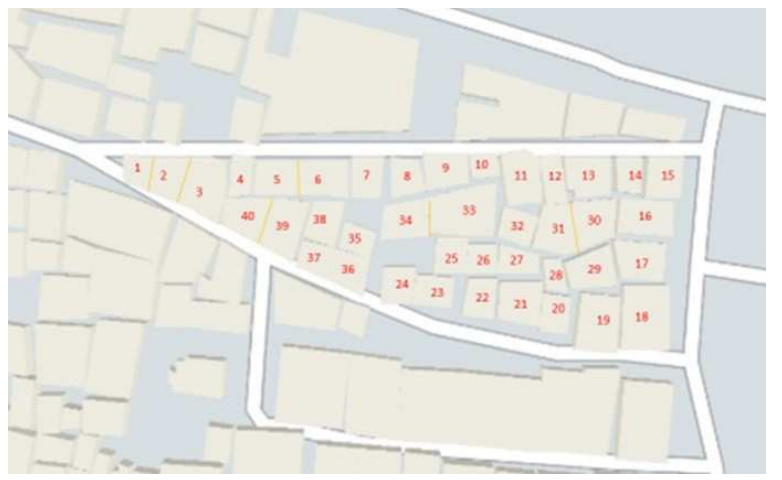

Fig. 5. Distribution of houses within the study area.

The outcome of the field study expresses both the author's observation of the physical conditions of the district and the results of the analysis based on residents' responses to the questionnaire. Although the site visits allowed for a useful observation of the physical built environment, the residents provided the most valuable insights into the lacking services, facilities, and needs for better living conditions.

\section{DESCRIPTIVE ANALYSIS OF THE EXISTING URBAN CONTEXT}

Jeddah has a significant rate of migration from other regions in Saudi Arabia, which contributes to the growth of the unplanned settlements. It seems that the development of low-cost housing in Jeddah cannot accommodate all migrants, and consequently, they find a home in these informal residential areas. The approximate population of Al-Sabeel District is 50625 inhabitants with a population density of 62019 people/sq km (Appendix C). Al-Sabeel has a significant number of expatriates; the majority of them are of African and Yemeni nationalities. They try to create their living environment, as best adapted to their economic capacity and cultural background, with hopes for modernization and urban development (Arab News, 2015). The literature review, observation during site visits, and the results of the interviews with the residents highlighted numerous different problems and critical issues that affect the living conditions in AlSabeel district. However, overcrowding, dilapidated buildings, small size dwellings, and inadequate streets are the main features of the district. The majority of streets are unnamed, including the main streets connecting the district with the city's road network. There is also a clear shortage of facilities and services such as schools and medical centres and a lack of open spaces and green areas, as it is confirmed by $88 \%$ of the survey participants (Table 1). In general, Al-Sabeel, as a neighborhood, is not well-planned, unhealthy, and ultimately unsafe.

Table 1. Responses of residents regarding the existing services in Al-Sabeel District.

\begin{tabular}{l|rr}
$\begin{array}{c}\text { Schools, clinics, } \\
\text { open spaces, and } \\
\text { green areas }\end{array}$ & $\begin{array}{c}\text { No. of } \\
\text { participants }\end{array}$ & $\begin{array}{c}\text { Share } \\
(\%)\end{array}$ \\
\hline Yes & 2 & 6 \\
No & 28 & 88 \\
Do not know & 2 & 6
\end{tabular}

\subsection{Site location and road network}

Al-Sabeel lies in the southern region of Jeddah and occupies about $816,273 \mathrm{sq} \mathrm{m}$. The district is bordered by four main roads, King Fahd Road in the northwest, King Khaled road in the southeast, Old Makkah road in the northeast, and the unnamed street1 in the southwest.

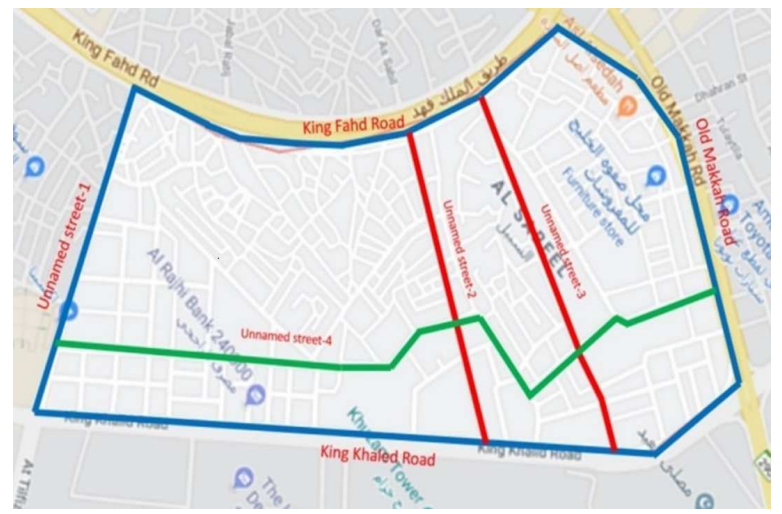

Fig. 6. Site location and the main streets in Al-Sabeel District.

There are two main internal streets; unnamed street-2 and unnamed street-3, which connect King Khaled road and King Fahd road. Also, there is another unnamed twisting street-4, which connects Old Makkah 
road and the unnamed street-1. Al-Sabeel is characterized by crowded internal narrow streets and high density of buildings, which in many cases obstruct the access to the essential street network. However, the road network of Al-Sabeel reflects a variety of street types, which vary in width, length, and functions (Fig. 6). Thus, there is a critical need to address part of these prevalent road network problems by innovative approaches that provide solutions and identify new opportunities.

\subsection{Al-Sabeel land use}

Al-Sabeel neighborhood comprises many different land uses, including residential, commercial, mixed commercial/residential, and public facilities and utilities. According to residents and the observation of
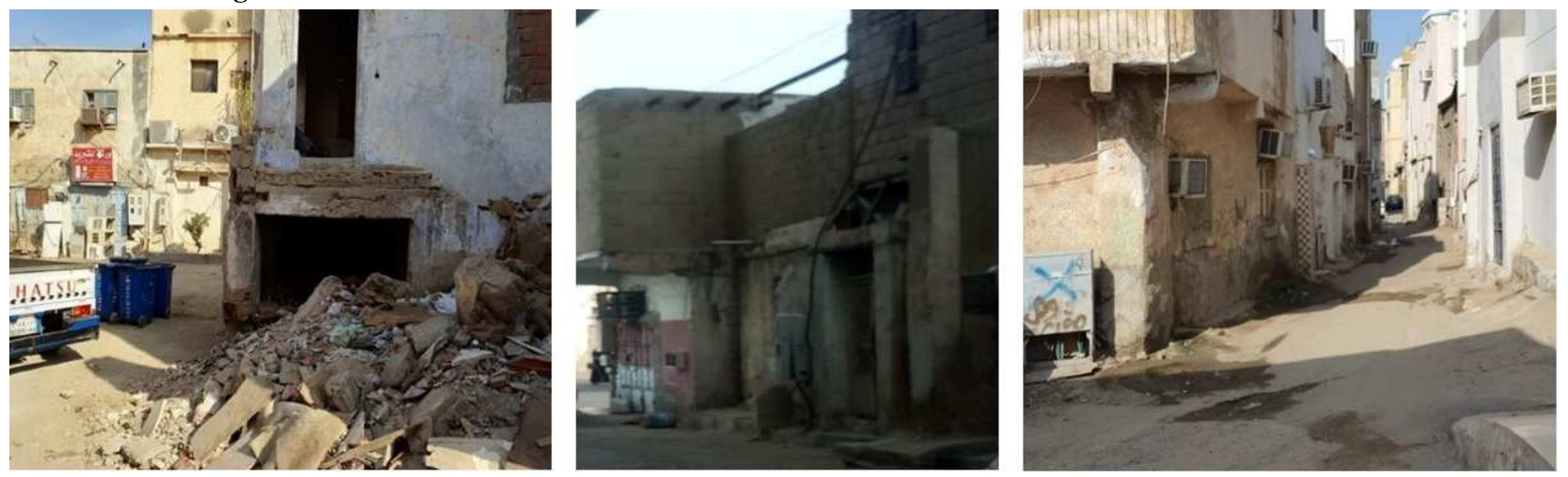

Fig. 7. Examples of buildings with deteriorated physical condition.
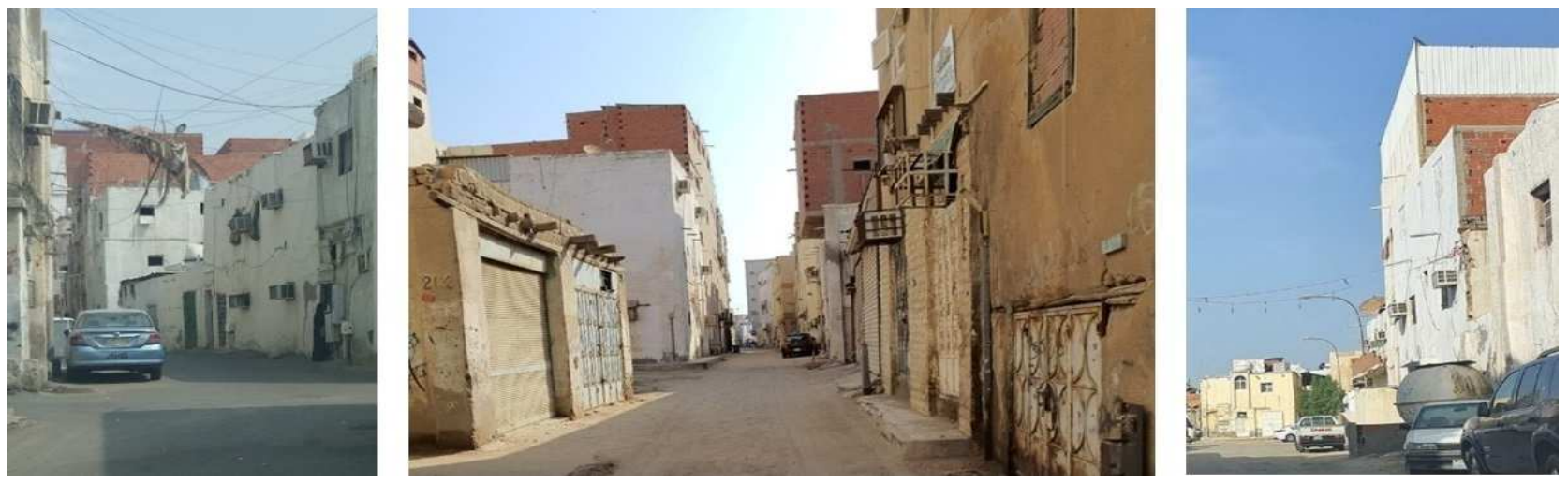

Fig. 8. Buildings of different heights in Al-Sabeel District.
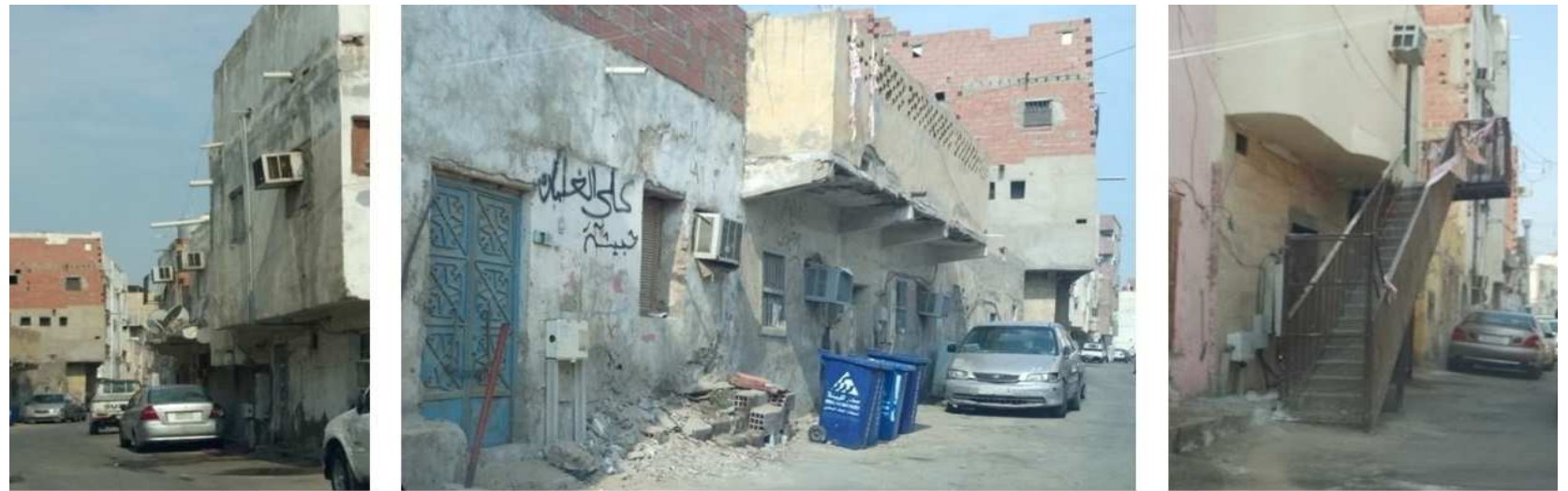

Fig. 9. Construction materials used for buildings in Al-Sabeel District. the field study, residential buildings occupy most of the land in the district, while commercial buildings, storages, and industrial buildings hold only a small share.

The field study also recorded significant deficiencies regarding areas providing entertainment and social life, along with the lack of roads, streets, lanes, and parking lots.

\subsection{Building conditions}

The majority of the buildings in Al-Sabeel district is mostly poor and tends to get worse. The survey results show that $66 \%$ of the buildings are in collapse (Fig. 7). poor physical condition, and many of them are about to 
Also about $28 \%$ of the buildings are in fair condition but need renovation, while only $6 \%$ of them are in good condition (Table 2).

This apparent contradiction among buildings of various levels of quality creates an unpleasant and disharmonious visual effect. The height varies as well (Fig. 8), but the most of them are one and two storey buildings representing $41 \%$ and $44 \%$ of the total number, according to the responses of participants. Three-storey buildings represent about 9\%, while the four-storey ones represent only 6\% (Table 3).

Many of Al-Sabeel buildings have been built illegally using many different construction materials (Fig. 9). While $63 \%$ of the buildings are built with cement blocks, for $28 \%$ of them reinforced concrete was used. Other supporting building materials such as stone, mud, and metal could be found and they were found in about $9 \%$ of the cases (Table 4 ).

Table 2. Residents' response regarding the physical condition of their buildings.

\begin{tabular}{l|rr}
\multicolumn{1}{c|}{$\begin{array}{c}\text { Building } \\
\text { condition }\end{array}$} & $\begin{array}{c}\text { No. of } \\
\text { participants }\end{array}$ & $\begin{array}{c}\text { Share } \\
(\%)\end{array}$ \\
\hline Poor & 21 & 66 \\
Fair & 9 & 28 \\
Good & 2 & 6
\end{tabular}

Table 3. Building heights - results of the survey.

\begin{tabular}{l|rr}
$\begin{array}{c}\text { Number of } \\
\text { floors }\end{array}$ & $\begin{array}{c}\text { No. of } \\
\text { participants }\end{array}$ & $\begin{array}{c}\text { Share } \\
(\%)\end{array}$ \\
\hline 1 floor & 13 & 41 \\
2 floors & 14 & 44 \\
3 floors & 3 & 9 \\
4 floors & 2 & 6
\end{tabular}

Table 4. Building materials - survey results.

\begin{tabular}{l|rr} 
Building material & $\begin{array}{c}\text { No. of } \\
\text { participants }\end{array}$ & $\begin{array}{c}\text { Share } \\
(\%)\end{array}$ \\
\hline Reinforced concrete & 9 & 28 \\
Cement block & 20 & 63 \\
Brick & 0 & 0 \\
Wood & 0 & 0 \\
Metal & 0 & 0 \\
Others & 3 & 9
\end{tabular}

\subsection{Infrastructure and hygiene problems}

Al-Sabeel is characterized by extremely deteriorated infrastructure and hygiene problems, which are responsible for the creation of an unhealthy and polluted environment for the residents (Fig. 10). For example, $56 \%$ of the respondents declared that many areas of the district are characterized by a bad smell coming from the uncollected rubbish, which exposes residents to health issues. Also, $53 \%$ of the survey participants agreed that the exposed electrical wires are common features of almost all buildings, which causes fear of sudden fire or hazards causing death. Furthermore, $69 \%$ of them believe that water and sewage piping systems are improper, inadequate, and affect the safety of their buildings. Residents confirmed that many streets are flooded with sewage water, which creates an unhealthy contaminated environment (Table 5).

Table 5. The residents' responses regarding the existing infrastructure and hygiene condition.

\begin{tabular}{|l|rc|}
\hline \multicolumn{1}{|c|}{ Rubbish } & $\begin{array}{c}\text { No. of } \\
\text { participants }\end{array}$ & $\begin{array}{c}\text { Share } \\
(\%)\end{array}$ \\
\hline Collected & 12 & 38 \\
Uncollected & 18 & 56 \\
Burnt & 2 & 6 \\
\multicolumn{1}{c|}{ Electrical wires } & $\begin{array}{c}\text { No. of } \\
\text { participants }\end{array}$ & $\begin{array}{c}\text { Share } \\
(\%)\end{array}$ \\
\hline Power box & 6 & 19 \\
Hidden in walls & 9 & 28 \\
Exposed outside the house & 17 & 53 \\
\hline Water and sewage pipes & $\begin{array}{r}\text { No. of } \\
\text { participants }\end{array}$ & $\begin{array}{c}\text { Share } \\
(\%)\end{array}$ \\
\hline Good & 2 & 6 \\
Fair & 3 & 9 \\
Deteriorated & 22 & 69 \\
Flooding streets & 5 & 16
\end{tabular}

\subsection{Mobility, accessibility, and open spaces}

Street networks have always been an essential tool that links and integrates the unplanned settlements to the overall system of the city. Site visits to Al-Sabeel district proved that there is a remarkable lack of public transport services and other facilities to be used during emergencies, such as fire, ambulance, and police vehicles.

Examination of the road network (Fig. 4) shows that the district is connected to the city main road network through two internal streets, but the many obstacles here do not allow easy access to these internal streets from the other numerous narrow streets and lanes (Fig. 11).

While $78 \%$ of the survey participants believe that the district's street network is unplanned in general, $44 \%$ of them stated that their houses lack any access to the main roads, and $37 \%$ have only partial access to the streets from their blocks. Besides, $81 \%$ of the interviewees confirmed that the district lacks parking lots, and consequently, cars block the narrow lanes for any emergencies (Table 6).

However, the absence of appropriately connected streets and lack of parking areas creates several problems that affect the mobility of the 
residents and consequently affect their daily life and
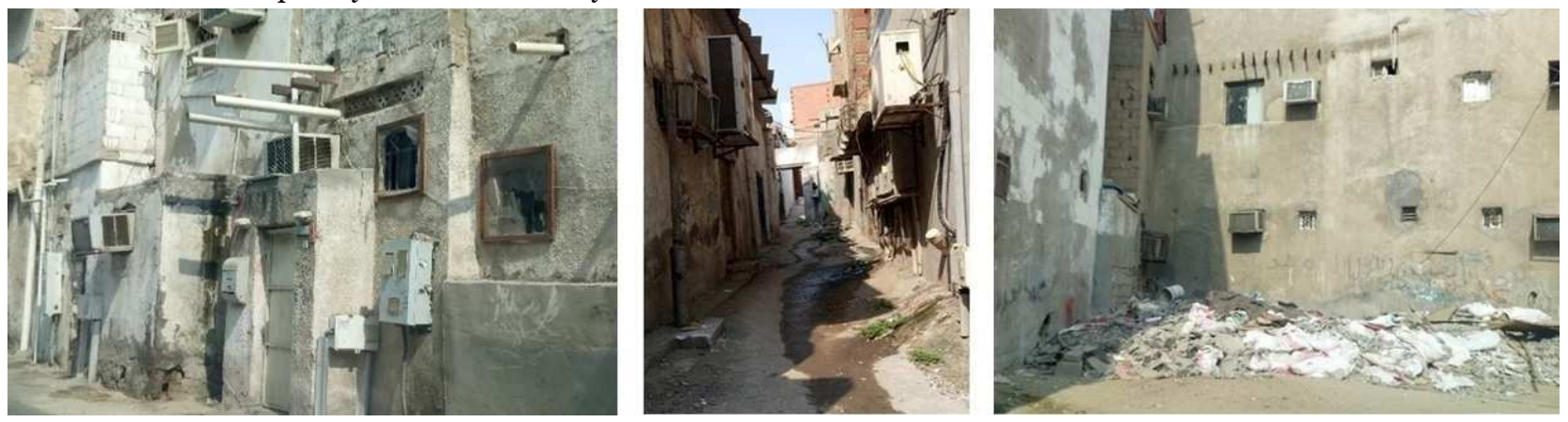

Fig. 10. Deteriorated infrastructure, exposed electrical wires, sewage, uncollected rubbish.
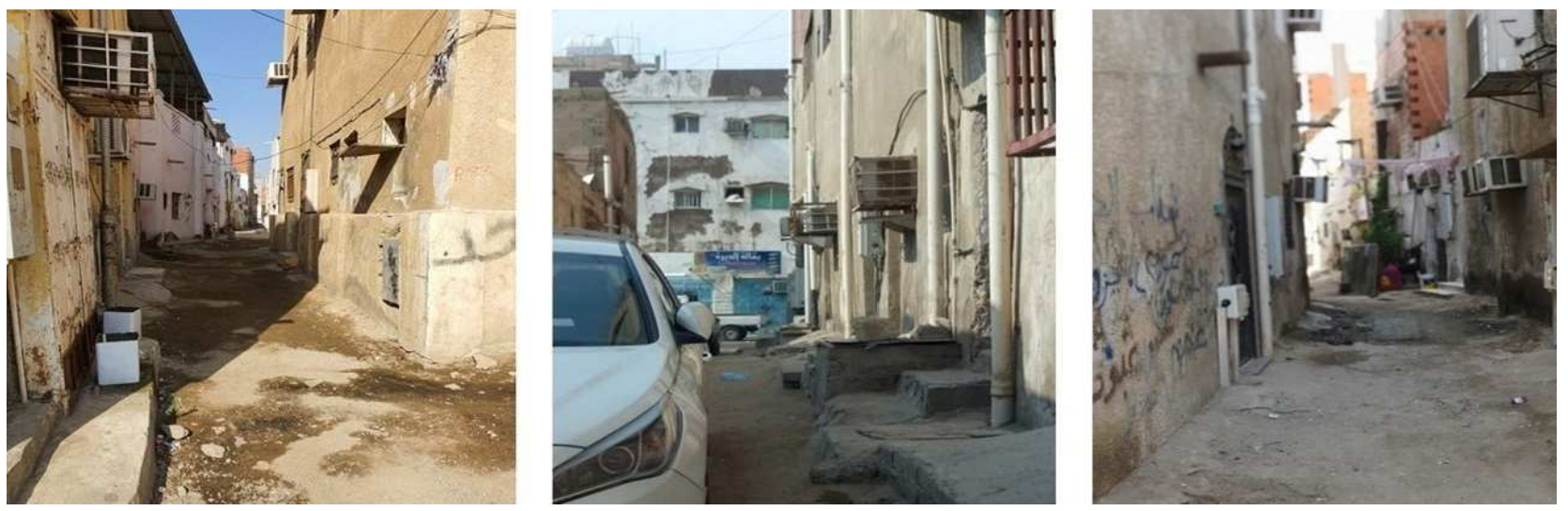

Fig. 11. Narrow street configuration dominating the district.

Table 6. Mobility and accessibility - survey results.

\begin{tabular}{|c|c|c|c|}
\hline $\begin{array}{c}\text { Street } \\
\text { network }\end{array}$ & $\begin{array}{c}\text { No. of } \\
\text { participants }\end{array}$ & $\begin{array}{c}\text { Share } \\
(\%)\end{array}$ & \\
\hline Planned & 7 & & 22 \\
\hline Unplanned & 25 & & 78 \\
\hline Accessibility & $\begin{array}{c}\text { No. of } \\
\text { participants }\end{array}$ & $\begin{array}{c}\text { Share } \\
(\%)\end{array}$ & \\
\hline Easy access & 6 & & 19 \\
\hline Partial access & 12 & & 37 \\
\hline No access & 14 & & 44 \\
\hline Parking lots & $\begin{array}{c}\text { No. of } \\
\text { participants }\end{array}$ & $\begin{array}{c}\text { Share } \\
(\%)\end{array}$ & \\
\hline Yes & 6 & & 9 \\
\hline No & 26 & & 81 \\
\hline
\end{tabular}

\section{DISCUSSION}

Like many Gulf cities, Jeddah represents a fast-growing city, which experiences a transformation on many different levels. Over the last few decades, Jeddah continues to deal with the consequences of rapid urban growth, including shortage of affordable housing and inadequate quality of public services, infrastructure, and environmental facilities (UNHABITAT, 2018). Informal and unplanned settlements are no longer marginalized neighborhoods that represent a small portion of the urban population in the world. They have become a distinct category of human settlements, which individualized within the fabric of modern cities, specifically in the developing world (Moreno and Warah, 2006). Statistics show that the number of slum dwellers increases by six million every year. Thus, the population of slums and unplanned settlements is expected to continuously grow if no appropriate and authoritative action is taken and implemented.

The subject of unplanned settlement is a complex one, not only for Saudi Arabia but worldwide, as well. The growth of slums and unplanned settlements today is a fact that will negatively affect the future urban regeneration of Saudi Arabia unless decisionmakers adopt a different approach that involves the community in the upgrading and development processes.

According to the United Nations report on sustainable development, there are many successful examples of unplanned settlements upgrading programs, which created community-housing initiatives, reduced poverty, and averted further slum growth, which were implemented in many different countries worldwide, namely Yemen, Jordan, Brazil, Philippines, Chile, and Costa Rica (United Nations, 2014). The survey revealed that $63 \%$ of the participants expressed willingness to serve in community projects voluntarily, while $28 \%$ of them are ready to work with a deriving benefit (Table 7). However, there is a need for government intervention, stakeholders, financial and 
political support, and experts to help in planning work activities. Slum upgrading is not only about extensively involving the residents in the development of their district but also about growing the whole community's ability to sustain itself. Although the concept of upgrading is not new, it holds promising results that can help with the problems of Al-Sabeel's built environment.

Table 7. Future upgrading and self-help participation - survey results.

\begin{tabular}{l|rrr}
\multicolumn{1}{c|}{$\begin{array}{c}\text { Future upgrading } \\
\text { projects }\end{array}$} & \multicolumn{1}{c}{$\begin{array}{c}\text { No. of } \\
\text { participants }\end{array}$} & $\begin{array}{c}\text { Share } \\
(\%)\end{array}$ \\
\hline Yes & 0 & 0 \\
No & 32 & 100 \\
\multicolumn{1}{c|}{$\begin{array}{c}\text { Community } \\
\text { participation }\end{array}$} & $\begin{array}{c}\text { No. of } \\
\text { participants }\end{array}$ & $\begin{array}{c}\text { Share } \\
(\%)\end{array}$ \\
\hline $\begin{array}{l}\text { Yes voluntarily } \\
\text { Yes with a deriving } \\
\text { benefit }\end{array}$ & 20 & 63 \\
No & 9 & 28 \\
\hline
\end{tabular}

More broadly, this paper indicates that AlSabeel settlement needs immense efforts to be recognized and visible in the public sphere. Although Jeddah municipality has made essential attempts to improve Al-Sabeel's built environment, the government should also define a set of strategies that would promote more social inclusion in the city. The central core of this argument is to bring the upgrading concept and community participation approach to the level of corporate discourse, to be expansive and encompassing. Officials should have the vision to explore the potential of community to be able to provide them with the appropriate solutions. Hou et al. (2015) believe that unplanned settlements embrace the potential of extraordinary design innovation, where scarcity and adversity breed ingenuity and resilience, and where nothing exists, everything is possible. Unplanned settlements have the potential to provide better living conditions, but they still face various challenging issues that need revolutionary solutions so as to achieve a better habitable environment for people. As cities are moving towards becoming smart in the future, they can also play a vital role in transforming these areas into lively neighborhoods and integrate them into broader urban development systems. Renovating these settlements with street networks, green spaces, and upgraded infrastructure would improve the physical living conditions and quality of people's lives, as well as reducing the associated health risks. One of the advanced solutions is to adopt the technological and digital applications that can cause a notable change in their future living conditions. The study showed that AlSabeel district is dense with buildings, which in many cases, block access to the essential streets network and hinder residents' movement. However, this problem could be overcome through innovative approaches that provide solutions and identify new opportunities, such as Map Kibera. It is one of the earliest digital technology and development projects expressing the significant interplay between technology and local slum communities. This project depends on trained young people from the community to survey their neighborhoods, and track roads using GPS devices, and then editing the map online in a computer laboratory. This technology has created the first open map of the Kibera slum in Nairobi in 2009 (Hagen, 2017). Another significantly advanced technology is the 'open Reblock' that creates a web-based platform to simplify the process of improving slum living conditions. This project intended to develop the existing street network of slums with the least-disruptive processes to provide access to their entire infrastructure (Open Reblock, 2015). The tool uses an algorithm to identify the best and simple reorganization of a cluster of blocks so that it can get access to the street. The 'open Reblock' was used successfully in Epworth neighborhood of Harare, in Zimbabwe, as well as in Khayelitsha, a township in Cape Town, South Africa (Brelsford, 2019).

Although these innovative solutions, which depend on smart applications, can play an essential role in the implementation of Al-Sabeel's upgrading road network, they must not be imposed on the district, but instead, they should be rooted in the urban context of the area and serve the realities of residents' living conditions. However, the cornerstone of Al-Sabeel's upgrading process is its residents, who conveyed a single overarching need, which is the improvement of the physical environment that can produce a very positive impact on their lives. The analysis shows that the residents voiced their concerns to play a role in the urban upgrading of their district. Thus, without reducing the cultural distance between the policymakers and members of Al-Sabeel's residents, there will be a lack of understanding of the essential components of the upgrading processes. Therefore, the authority in Jeddah needs to fully exploit the community's ability to contribute, to some extent, to the implementation of any proposed upgrading project. The standpoint of this discussion is that the engine of change is the residents of Al-Sabeel, who should be mobilized to help in the development process, and without a strategy for long-term participation, no project will be truly sustainable.

\section{CONCLUSION}

The authority in Jeddah has undertaken many noteworthy steps towards the improvement of living conditions in many of the unplanned settlements, including Al-Sabeel, but they could not keep pace with the rapid population growth in these areas. The growth of these unplanned settlements could be attributed to 
the lack of sustainable housing policy in Jeddah. The government has enough resources allocated to improve and maintain the infrastructure and services, but they have faced many problems and obstacles that delayed the development of these areas. Meanwhile, several organizations made efforts and investments to control the growth of the unplanned areas, but without consideration to a sustainable urban development proposal to solve the problem. In this context, government policies and strategies involving the demolition of informal settlements and slums need to be critically questioned. While the objectives of unplanned settlements and slum upgrading of the city of Jeddah can be understood as part of a broader ideal urban development model, the lives of residents, who are disadvantaged and already marginalized, remain flawed. For example, what is reflected in Al-Ruwais proposal (Fig. 3) is the shift towards modern, visually attractive vertical housing instead of the existing local urban patterns, which is based on the residents' views on their livelihoods. Thus, Jeddah's authority needs to understand the implications of the residents' lives when applying the replacement approach and to address and consider their concerns.

Al-Sabeel's unplanned settlement has its individuality, and it indeed differs from other slums in Jeddah. It represented a culture of deficiency and was noticeable for its lack of civic amenities, which stood out against the backdrop of the progressive character of Jeddah city. The strength of a slum or unplanned settlement lies in its physical infrastructure, including street connectivity, access to improved sanitation, tapped water, sewerage, and power supply. Therefore, the city of Jeddah should adopt a broader challenge of ensuring equity in the provision of these infrastructures and services. In addition, the poor living condition in Al-Sabeel's deteriorating built environment affects the health of people mentally and physically and can cause diseases. Also, as these deteriorating areas remain isolated from the rest of the urban society, they will create serious social and deviant behavioral problems such as crime, vandalism, drug abuse, alcoholism and crime. However, Al-Sabeel settlement should not only be studied in the context of its physical condition but also the social dimension, which requires an interdisciplinary approach, should be considered. There is still a need for more in-depth investigations of the social structure of the district, which is beyond the scope of this paper. Thus, extensive research is needed to help and support the government to find appropriate solutions to this pressing problem.

In this regard, the importance of community participation approach as a means of improving the physical condition of the urban environment and uplifting residents from a degrading quality of life is recommendable. Hence, the authority and other stakeholders should abandon the prevailing idea of slum clearance, and the construction of a new housing 90 approach. Instead, they should determine what works for such unplanned settlements and tailor a specific development plan that would correspond to their contextual situation. In addition, the urban authority needs to develop innovative ideas to solve the district's problems and improve the physical environment.

Also, Al-Sabeel residents should not be seen just as beneficiaries but as the primary stakeholders, as well as the focal point of developing the physical built environment. Finally, while the collected survey data provide a considerable measure of the physical status of the built environment of Al-Sabeel, it is often not precise enough due to difficulties in identifying and interviewing a more significant portion of the residents. However, the survey's results of this research may not be necessarily generalized for all the informal settlements of Saudi Arabia and hence requires the inclusion of other representative case studies for slums and unplanned settlements.

No doubt, improving living conditions in unplanned settlements is a critical challenge that Jeddah will face over the next few decades, and AlSabeel settlement may remain vulnerable to being designated for redevelopment and eviction by the government.

\section{RECOMMENDATION}

The study covered the analysis of the physical context of Al-Sabeel, which is an essential component of what constitutes a healthy environment for the community. The survey has brought essential issues that affect the physical condition of the district and have an impact on the welfare of the residents, such as lack of properly connected street network, dilapidated houses and deteriorated infrastructure. These problems should be viewed within the context of finding appropriate minimum intervention solutions, without replacing or removing the entire district. The following are some of the recommendations that could mitigate the problems that residents face and provide valuable insights towards the development and upgrading of similar unplanned settlements.

a). Local authorities should be actively involved in implementing infrastructure projects with a vision of sustaining the wellbeing of the district's inhabitants.

b). Jeddah municipality should manage the upgrading of Al-Sabeel district by consulting the residents in the proposed renovation plans and considering their sense of place and social network.

c). The government should consider the demolition of the abandoned, dilapidated houses, which evoke fear and a rapid decline in the health and welfare of the community. The demolition of these houses represents a potential opportunity to preserve the land and establish new open green spaces or parking areas. They will also help enhancing the environmental quality 
of the district and provide a sense of pride to the inhabitants.

d). The existing street network, specifically the internal one, needs a thoughtful study to find practical and innovative solutions that create smooth movement, ensure safety, and connect it to the city's main network.

e). A framework of the community self-help plan could be considered to encourage the residents of $\mathrm{Al}$-Sabeel to take part in the development while keeping their own identity.

g). The government and the public sectors can play a significant role in solving the problem of unplanned settlements by investing in infrastructure improvement schemes as well as financing low-income housing programs.

h). Finally, as this research focused on analyzing the physical built environment, a more indepth study in the area of upgrading as an alternative means of intervention would be of great help in the future. For example, further studies should be conducted in order to examine what other factors, such as migration, lack of education, health issues, socioeconomic, and environmental, may affect the improvement programs of slums and informal settlements.

\section{ACKNOWLEDGMENTS}

The author would like to express his appreciation for the Graduate Studies and Research at Effat University for their continuous support to realizing this research.

\section{REFERENCES}

Al-Faraj T. (2014), The fall of the neighbourhood in Makkah newspaper. URL: https://makkahnewspaper .com/article/52073. Accessed on 12.11.2019.

Al-Malki M. (2008), Squatter Settlement in Jeddah: Causes, Characteristics \& Dimensions. A thesis for the Master degree in Geography, King Abdulaziz university, Faculty of Arts and human sciences, Jeddah, Saudi Arabia.

Arab News (2015), Jeddah's The Al-Sabeel district becomes a cause of worry. URL: https://www. arabnews.com/saudi-rabia/news/789591. Accessed on 12.8.2019.

Brelsford C., Martin T., Bettencourt L. (2019), Optimal reblocking as a practical tool for neighbourhood development. Environment and Planning B. Urban Analytics and City Science, 46(2): p. 303-321.

Carpenter C. M., Suto M. (2008), Qualitative research for occupational and physical therapists: a practical guide. Oxford: Wiley.

Das A., King R. (2019), Surabaya: The Legacy of Participatory Upgrading of Informal Settlements. URL: https://www.wri.org/wri-tiesforall/publication/ surabaya-legacy-participatory-upgrading-informalsettlements. Accessed on 22.1.2020.

Drakakis-Smith D. (1981), Urbanisation, Housing, and the Development Process. Croom Helm, London. https://doi.org/10.1002/pad.4230020212

Ghamdi F. A. (2007), Jeddah Municipality begins the demolition of 165 buildings in Al Sabeel neighbourhood for re-planning. Alhayat, Jeddah.

Hagen E. (2017), Open mapping from the ground up: learning from Map Kibera, Making All Voices Count Research Report, p.5-8. URL: https://opendocs.ids.ac. uk/opendocs/bitstream/handle/20.500.12413/13244/R Report_MapKibera_Online.pdf. Accessed on 12.2.2020.

Hou J., Spencer B., Way T., Yocom K. (2015), Now Urbanism: The Future City is Here. London: Routledge.

JDURC (n.d.), Jeddah Development \& Urban Regeneration Co. URL: http://jdurc.com/en/wwa. aspx?mid=13\&msid=18\&mssid=0. Accessed on 23.10.2019.

Karimia K. (2012), A configurational approach to analytical urban design: 'Space syntax' methodology. URBAN DESIGN International, vol. o, o, 1-22, p.17. https://doi:10.1057/udi.2012.19

Minnery J., Argo T., Winarso H., Hau D., Veneracion C., Forbes D., Childs I. (2013), Slum upgrading and urban governance: Case studies in three southeast Asian cities. Habitat International, 39: p. 162169. https://doi.org/10.1016/j.habitatint.2012.12.002

Moreno E. L., Warah R. (2006), STATE OF THE WORLD'S CITIES 2006/7. United Nations Human Settlements Programme. p.14. URL: https://sustainable development.un.org/content/documents/11292101_alt. pdf. Accessed on 16.1.2020.

Open Reblock (2015), Santa Fe Institute \& the Regents of the University of California. URL: https://openreblock.org/about.html. Accessed on 22.1.2020.

Patel K. (2013), A successful slum upgrade in Durban: A case of formal change and informal continuity. Habitat International. 40: p. 216. https://doi.org/ 10.1016/j.habitatint.2013.05.005

UNESCAP (2015), The State of Asian and Pacific. UNHabitat, Nairobi, Kenya. URL: https://www.unescap. org/sites/default/files/The\%2oState\%20of\%20Asian\% 20and\%20Pacific\%20Cities\%202015.pdf. Accessed on 22.9.2019.

UN-Habitat (2003), The Challenge Of Slums: Global Report On Human Settlements. Earthscan Publications. URL: https://www.un.org/ruleoflaw/files/Challenge \%20of\%20Slums.pdf. Accessed on 3.12.2019.

UN-HABITAT (2011), Cairo: A City in Transition. cities \& citizens series bridging the urban divide. United Nations Human Settlements Programme. P.6,135. URL: https://unhabitat.org/sites/default/files/downloadmanager-files/Cairo\%20\%20a\%20City\%20in\%20 Transition.pdf

UN-Habitat (2012), Streets as Tools for Urban Transformation in Slums: A Street-Led Approach to 
Citywide Slum Upgrading. United Nations Human Settlements Programme: Nairobi. URL: https://www. ohchr.org/Documents/Issues/Housing/InformalSettle ments/UNHABITAT_StreetsasToolsforUrbanTransfor mationinSlums.pdf. Accessed on 18.1.2020.

UN-Habitat (2015), Habitat III Issue Papers 22Informal Settlements. Nairobi, Kenya. URL: https://unhabitat.org/wp-content/uploads/2015/o4/ Habitat-III-Issue-Paper22_Informal-Settlements.pdf. Accessed on 18.10.2019.

UN-Habitat 3 (2015), United Nations General Assembly. New Urban Agenda. URL: http://habitat3. org/the-newurban-agenda/. Accessed on 18.11.2019.

UN-Habitat (2016), Slum Almanac 2015/2016Tracking the Lives of Slum Dwellers. Nairobi, Kenya. URL: https://unhabitat.org/wp-content/uploads/2016/ 02-old/Slum\%20Almanac\%2020152016_EN.pdf.

Accessed on 25.10.2019.

UN-HABITAT (2018), Future Saudi Cities Programme. Ministry of Municipal and rural Affairs. p.4, 6, 19. URL: https://www.futuresaudicities.org/cpireports/CPI\%20Profile\%2ofor\%2OJeddah.pdf.

Accessed on 14.9.2019.

UNICEF (2012), Upgrading Informal Settlement in Jeddah. THE STATE OF THE WORLD'S CHILDREN, p.65. URL: https://www.unicef.org/sowc2012/pdfs/ SOWC-2012-Focus-On-Upgrading-informalsettlements.pdf. Accessed on 22.8.2019.

United Nations (2014), Sustainable Development in action: Human Settlements: Towards Sustainable Communities. Department of Public Information. URL: https://www.un.org/esa/sustdev/csd/csd12/backgroun der_hs.pdf. Accessed on 14.10.2019.

World Cities Report (2016), Urbanization and Development: Emerging Futures. UN-Habitat, Nairobi, Africa. URL: https://unhabitat.org/wp-content/ uploads/2014/o3/WCR-\%2oFull-Report-2016.pdf.

Accessed on 23.10.2019.

World Population Review (n.d.). URL: http://world populationreview.com/countries/saudi-arabiapopulation/. Accessed on 16.2.2020.

APPENDIX A. Urban Unplanned Settlements in Saudi Arabia, Case Study: ALSabeel District, Jeddah Questionnaire - Faceto-face interview

This questionnaire intends to investigate the physical condition and common problems of Al-Sabeel district in Jeddah City. The questionnaire is divided into four sections, including personal information, building physical conditions, infrastructure problems, and mobility and accessibility. The outcome of the questionnaire will help to analyze and assess the built environment of the district. All information mentioned in this questionnaire will be strictly confidential.

\section{A. General Information}

1. Your name

2. Have the residents of the district been informed about any future upgrading project?

$$
\text { Yes - No }
$$

3. What is the prevailing building type in the district?

4. Would you participate in a self-help community project to improve the district's physical condition? Yes voluntarily - Yes with deriving benefit No

\section{B. Building physical condition}

1. What is the building material for your house? Reinforced concrete - Cement block - Brick -

Wood - Metal - Others

2. How many floors in your house? One floor - Two floors - Three floors - Four

floors

3. What is the physical condition of your house?

$$
\text { Poor-Faire - Good }
$$

\section{Infrastructure and Hygiene problems}

What is the status of the district's infrastructure and hygiene conditions?

1. Rubbish

$$
\text { Collected - Partially collected - Uncollected - }
$$

Burnt

2. Electrical wires

$$
\text { Power-box - Hidden in walls - Exposed }
$$
outside the house.

3. Water and sewage pipes

Good - Fair - Deteriorated - Flooding streets

\section{Mobility, accessibility, and Open spaces}

1. Street network

$$
\text { Planned - Unplanned }
$$

2. Are all the internal streets and lanes have access to the main road?

Easy access - Partial access - No access

3. Are there parking lots for the resident's cars?

$$
\text { Yes - No }
$$

\section{E. Services}

1. Are there adequate schools, clinics, open spaces, and gardens for social life activities?

$$
\text { Yes - No - Do not know }
$$


APPENDIX B. Number of residents/unit \& Buildings' height, material, and physical condition.

\begin{tabular}{|c|c|c|c|c|c|c|}
\hline \multirow{2}{*}{ No. } & \multirow{2}{*}{ Person } & \multirow{2}{*}{$\begin{array}{l}\text { Height/ } \\
\text { Floor }\end{array}$} & \multirow{2}{*}{ Material } & \multicolumn{3}{|c|}{ Building Condition } \\
\hline & & & & Poor & Fair & Good \\
\hline 1 & 12 & 2 & Cement Block & $\sqrt{ }$ & & \\
\hline 2 & 12 & 2 & Reinforced Concrete & $\sqrt{ }$ & & \\
\hline 3 & 6 & 1 & Cement Block & $\sqrt{ }$ & & \\
\hline 4 & 6 & 1 & Cement Block & $\sqrt{ }$ & & \\
\hline 5 & 6 & 1 & Cement Block & $\sqrt{ }$ & & \\
\hline 6 & 24 & 4 & Reinforced Concrete & & $\sqrt{ }$ & \\
\hline 7 & 12 & 2 & Reinforced Concrete & $\sqrt{ }$ & & \\
\hline 8 & 12 & 2 & Cement Block & & $\sqrt{ }$ & \\
\hline 9 & 12 & 2 & Cement Block & & $\sqrt{ }$ & \\
\hline 10 & 12 & 2 & Cement Block & $\sqrt{ }$ & & \\
\hline 11 & 12 & 2 & Reinforced Concrete & $\sqrt{ }$ & & \\
\hline 12 & 12 & 2 & Cement Block & $\sqrt{ }$ & & \\
\hline 13 & 12 & 2 & Cement Block & $\sqrt{ }$ & & \\
\hline 14 & 6 & 1 & Reinforced Concrete & $\sqrt{ }$ & & \\
\hline 15 & 12 & 2 & Reinforced Concrete & $\sqrt{ }$ & & \\
\hline 16 & 12 & 2 & Cement Block & $\sqrt{ }$ & & \\
\hline 17 & 18 & 3 & Reinforced Concrete & & & $\sqrt{ }$ \\
\hline 18 & 12 & 2 & Cement Block & & $\sqrt{ }$ & \\
\hline 19 & 12 & 2 & Reinforced Concrete & . & $\sqrt{ }$ & \\
\hline 20 & 12 & 2 & Reinforced Concrete & . & $\sqrt{ }$ & \\
\hline 21 & 24 & 4 & Reinforced Concrete & 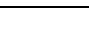 & & $\sqrt{ }$ \\
\hline 22 & 6 & 1 & Cement Block & $\sqrt{ }$ & & \\
\hline 23 & 6 & 1 & Cement Block & $\sqrt{ }$ & & \\
\hline 24 & 6 & 1 & Cement Block & $\sqrt{ }$ & & \\
\hline 25 & 6 & 1 & Cement Block & $\sqrt{ }$ & & \\
\hline 26 & 6 & 1 & Cement Block & $\sqrt{ }$ & & \\
\hline 27 & 6 & 1 & Cement Block & $\sqrt{ }$ & & \\
\hline 28 & 6 & 1 & Cement Block & $\sqrt{ }$ & & \\
\hline 29 & 6 & 1 & Cement Block & $\sqrt{ }$ & & \\
\hline 30 & 6 & 1 & Cement Block & $\sqrt{ }$ & & \\
\hline 31 & 6 & 1 & Cement Block & $\sqrt{ }$ & & \\
\hline 32 & 6 & 1 & Cement Block & $\sqrt{ }$ & & \\
\hline 33 & 6 & 1 & Cement Block & $\sqrt{ }$ & & \\
\hline 34 & 18 & 3 & Reinforced Concrete & & $\sqrt{ }$ & \\
\hline 35 & 12 & 2 & Reinforced Concrete & $\sqrt{ }$ & & \\
\hline 36 & 18 & 3 & Reinforced Concrete & & $\sqrt{ }$ & \\
\hline 37 & 12 & 2 & Cement Block & & $\sqrt{ }$ & \\
\hline 38 & 6 & 1 & Cement Block & $\sqrt{ }$ & & \\
\hline 39 & 12 & 2 & Cement Block & & $\sqrt{ }$ & \\
\hline 40 & 12 & 2 & Cement Block & $\sqrt{ }$ & & \\
\hline Total & 420 & & & 28 & 10 & 2 \\
\hline$\%$ & & & & 70 & 25 & 5 \\
\hline
\end{tabular}


APPENDIX C. Calculations of the density of Al-Sabeel district.

\begin{tabular}{|l|l|l|}
\hline & Calculations & Source \\
\hline Area of Al-Sabeel District & $816273 \mathrm{~m}^{2}=0.816273 \mathrm{Km}^{2}$ & Google map \\
\hline Area of the study zone & $6772 \mathrm{~m}^{2}$ & Google map \\
\hline Study zone population & 420 person & Appendix B \\
\hline The approximate population of Al-Sabeel & $816273 / 6772 \times 420=50625$ persons & \\
\hline The density of Al-Sabeel district & $50625 / 816273 \times 1000000=62019$ persons $/ \mathrm{Km}^{2}$ & \\
\hline
\end{tabular}

